\title{
Health care-associated infections - an overview
}

This article was published in the following Dove Press journal: Infection and Drug Resistance

\section{Mainul Haque' \\ Massimo Sartelli \\ Judy McKimm \\ Muhamad Abu Bakar' \\ 'Faculty of Medicine and Defence Health, Universiti Pertahanan Nasional Malaysia (National Defence University of Malaysia), Kem Sungai Besi, 57000 Kuala Lumpur, Malaysia; ${ }^{2}$ Department of Surgery, Macerata Hospital,Via Santa Lucia 2, 62100 Macerata, Italy; ${ }^{3}$ Swansea University School of Medicine, Swansea University, Singleton Park, Swansea, Wales SA2 8PP, UK}

Video abstract

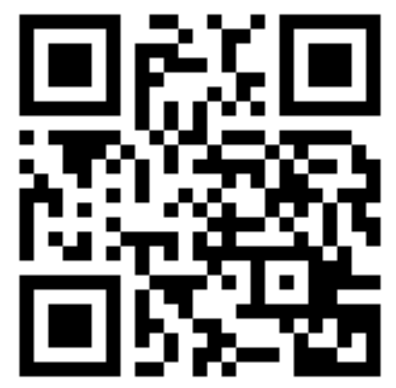

Point your SmartPhone at the code above. If you have a QR code reader the video abstract will appear. Or use: http://youtu.be/a0QIqq4d0io

Correspondence: Mainul Haque Faculty of Medicine and Defence Health, Universiti Pertahanan Nasional Malaysia (National Defence University of Malaysia), Kem Sungai Besi, 57000 Kuala Lumpur, Malaysia

Mobile +60 109265543

Email runurono@gmail.com

\begin{abstract}
Health care-associated infections (HCAIs) are infections that occur while receiving health care, developed in a hospital or other health care facility that first appear 48 hours or more after hospital admission, or within 30 days after having received health care. Multiple studies indicate that the common types of adverse events affecting hospitalized patients are adverse drug events, HCAIs, and surgical complications. The US Center for Disease Control and Prevention identifies that nearly 1.7 million hospitalized patients annually acquire HCAIs while being treated for other health issues and that more than 98,000 patients (one in 17) die due to these. Several studies suggest that simple infection-control procedures such as cleaning hands with an alcohol-based hand rub can help prevent HCAIs and save lives, reduce morbidity, and minimize health care costs. Routine educational interventions for health care professionals can help change their hand-washing practices to prevent the spread of infection. In support of this, the WHO has produced guidelines to promote hand-washing practices among member countries. Keywords: health care-associated infections, central line-associated bloodstream infections, surgical site infections, catheter-associated urinary tract infections, ventilator-associated pneumonia
\end{abstract}

\section{Background}

Health care-associated infections (HCAIs) are those infections that patients acquire while receiving health care. ${ }^{1}$ The term HCAIs initially referred to those infections linked with admission to an acute-care hospital (earlier called nosocomial infections), but the term now includes infections developed in various settings where patients obtain health care (eg, long-term care, family medicine clinics, home care, and ambulatory care). HCAIs are infections that first appear 48 hours or more after hospitalization or within 30 days after having received health care. ${ }^{2}$ Multiple studies indicate that the most common types of adverse events affecting hospitalized patients are adverse drug events, HCAIs, and surgical complications. ${ }^{3-7}$ The US Center for Disease Control and Prevention identifies that nearly 1.7 million hospitalized patients annually acquire HCAIs while being treated for other health issues and that more than 98,000 of these patients (one in 17) die due to HCAIs. ${ }^{8}$ The Agency for Health care Research and Quality reported that HCAIs are the most common complications of hospital care and one of the top 10 leading causes of death in the USA. ${ }^{9}$ Out of every 100 hospitalized patients, seven patients in advanced countries and ten patients in emerging countries acquire an HCAI. ${ }^{10}$ Other studies conducted in high-income countries found that $5 \%-15 \%$ of the hospitalized patients acquire HCAIs which can affect from $9 \%$ to $37 \%$ of those admitted to intensive care units (ICUs). ${ }^{11,12}$ Multiple research studies 
report that in Europe hospital-wide prevalence rates of HCAIs range from $4.6 \%$ to $9.3 \% .{ }^{13-21}$ The WHO reports however that HCAIs usually receive public attention only when there are epidemics. ${ }^{22}$ HCAIs also have impact on critically ill patients with around 0.5 million episodes of HCAIs being diagnosed every year in ICUs alone. ${ }^{7,14,23}$ ICU patients are often in a very critically ill, immuno-compromised status which increases their susceptibility to HCAIs. ${ }^{24,25}$

\section{Brief history}

There has been long-standing awareness that the practice of medicine can do harm as well as good. For example, Hippocrates, the father of modern medicine, stated more than 2,500 years ago that "I will use treatments for the benefit of the ill in accordance with my ability and my judgment, but from what is to their harm and injustice I will keep them."26 It was also recognized (eg, by Semmelweis discussing puerperal fever) many years ago that coming into hospitals (in particular) can be dangerous. ${ }^{27}$ In this century, the idea that medicine could cause harm, including death is described as "unintended physical injury resulting from or contributed to by medical care, including ... [its] absence ... that requires additional monitoring, treatment or hospitalization, or ... results in death." ${ }^{28,29}$ Offering another perspective, an American natural sciences writer noted that HCAIs are now killing around 100,000 people, many more than HIV/AIDS, cancer, or road traffic accidents. ${ }^{30}$

The Hungarian obstetrician Professor (Dr) Ignaz Phillip Semmelweis is largely considered as the medical doctor who realized that health care providers could communicate disease. His work identified the mode of communication and spread of puerperal sepsis while working at the Maternity Hospital in Vienna. In 1847, he observed higher rates of maternal mortality among patients treated by obstetricians and medical students than among those cared for by midwives. At that time, he also found that a pathologist had died of sepsis after wounding himself with a scalpel while carrying out an autopsy on a patient with puerperal sepsis. The pathologist's illness mirrored that of women with puerperal sepsis, and Semmelweis wrote that both a scalpel and a physicians' contaminated hands could transmit organisms to mothers during labor. He introduced chlorinated lime hand washing to the obstetric hospital staff, resulting in large improvements in maternal mortality rates. ${ }^{31}$ However, Semmelweis' theories were dismissed by most of the medical establishment because of a lack of appropriate statistical analysis of the data. Nevertheless, after Koch's postulates were published in 1890 , the germ theory of disease and
Semmelweis' theory of transmission of disease from doctor to patient were found to be valid. Semmelweis was therefore the first to describe an HCAI and provide an intervention to avert its spread through hand hygiene. ${ }^{32}$

\section{Prevalence and brief outline of HCAls}

A survey conducted in 183 US hospitals with 11,282 patients reported that $4 \%$ of patients had at least one HCAI with the most common microorganism being Clostridium difficile. Most infections were surgical site infections (SSIs), pneumonia, and gastrointestinal infections. ${ }^{33}$ A study 2 years earlier by the same group found that $6 \%$ (51) of patients had suffered from HCAIs with the top $75.8 \%$ acquiring SSIs, urinary tract infections (UTIs), pneumonia, and bloodstream infections. Staphylococcus aureus was the most frequently detected microorganism. ${ }^{34}$ The group conducted a comparative study between 2011 and 2015 and found a statistically significant $(P<0.05)$ reduction of HCAIs in SSIs, UTIs, and central line infections, probably due to a national initiative. ${ }^{35}$

HCAIs are also problematic elsewhere in the world. For example, a study in Singapore reported 11.9\% (646) patients with HCAIs, primarily undetermined clinical sepsis, and pneumonia caused mainly by $S$. aureus and Pseudomonas aeruginosa. ${ }^{36}$ This study also reported that the Acinetobacter species and $P$. aeruginosa were extremely resistant to carbapenem. ${ }^{36}$ A recent European study found that 2,609,911 new patients were identified as having HCAIs annually in the European Union and European Economic Area. ${ }^{37}$ This study revealed that for every 20 patients hospitalized, at least one acquired an HCAI which was preventable. ${ }^{37}$ Klebsiella pneumoniae and the Acinetobacter species were exceedingly resistant to multiple antimicrobials, and the lack of new antimicrobials increases the huge burden in Europe. ${ }^{37}$ In Greece, the HCAI prevalence rate was 9.1\%. The frequent types of HCAIs were lower respiratory tract infections (LRTIs), bloodstream infections, UTIs, SSIs, and systemic infections. ${ }^{38}$ One systematic review and meta-analysis regarding HCAIs in Southeast Asian countries (Brunei, Myanmar, Cambodia, East Timor, Indonesia, Laos, Malaysia, the Philippines, Singapore, Thailand, and Vietnam) found an overall prevalence rate of $9.1 \%$ with the most common microorganisms being $P$. aeruginosa, the Klebsiella species, and Acinetobacter baumannii. ${ }^{39}$

A study conducted in eight university hospitals of Iran (ranging from 60 to 700 beds) reported an overall HCAI frequency of $9.4 \%$, the most common HCAIs were bloodstream infections, SSIs, UTIs, and pneumonia. ${ }^{40}$ A logistic regression analysis showed that the odds ratio $(\mathrm{OR})$ for males 
as opposed to females acquiring infections was $1.56(95 \%$ confidence interval [CI] 1.21-2.02). Additional risk factors for HCAIs include a central intravascular catheter, adjusted OR of 3.86 (95\% CI 2.38-6.26), and with a urinary catheter, adjusted OR of 3.06 (95\% CI 2.19-4.28). Being admitted to an ICU is not in itself a self-determining HCAI risk factor. The OR for all HCAIs of acquiring an infection was 3.24 (95\% CI 2.34-4.47) in patients with hospital stays longer than 8 days. ${ }^{33}$ Seventy-one percentage $(71 \%)$ of the studied patients received antimicrobials, but $9.4 \%$ had at least one evidence of infection. ${ }^{33}$ Another study revealed that the average number of microbes ranged from on $(9.67 \times 1011)$, working surfaces $(1.64 \times 1012)$, door handles $(1.71 \times 1012)$, and highest in taps $(2.08 \times 1012) .{ }^{41}$ The highest number $(23)$ of pathogens were isolated from door handles, and the peak variance of pathogens were on hospital floors (7). Among those microbes, those that were disease-producing were $46.14 \%, 53.86 \%$ were nonpathogenic, the most common was S. aureus at $14.42 \%$ and $45.2 \%$ of the total bacterial isolates comprised Bacillus subtilis. A study conducted in Ghana reported that gentamicin was the most effective antibiotic $(100 \%)$ on both Gram-positive and Gram-negative organisms, but of the 12 antibiotics tested (ampicillin, cefuroxime, cotrimoxazole, cefotaxime, tetracycline, amikacin, gentamicin, chloramphenicol, cefixime, cloxacillin, and erythromycin), six were resistant to either Gram-positive or Gram-negative organisms. ${ }^{41}$ Most of the HCAIs in the US are triggered by the ESKAPE group, comprising the antimicrobial-resistant Gram-negative microorganisms (K. pneumoniae, A. baumannii, P. aeruginosa, and Enterobacter spp.) and the Grampositive species, Enterococcus faecium and $S$. aureus. ${ }^{42-44}$ Multiple studies report that Gram-negative organisms are responsible for $10 \%,{ }^{45} 20 \%-40 \%,{ }^{46}$ of HCAIs and that antimicrobial resistance places a significant burden on the global health care system, particularly in low resource countries..$^{47,48}$ This problem is exacerbated as research and development into new antimicrobials targeting Gram-negative organisms has rapidly decreased in recent years. ${ }^{48}$

Among the newer aminoglycosides, plazomicin has been found to be active against the extended-spectrum betalactamase (ESBL) generating strains of Enterobacter spp., Escherichia coli, and K. pneumonia ${ }^{49}$ and more effective in laboratory experiments against $A$. baumannii than gentamicin, tobramycin, and amikacin. ${ }^{50}$ Plazomicin has a better safety profile than other drugs, with no report of damage to the cochlea, auditory nerve, vestibular, and renal system in healthy volunteers, even with high and multiple doses. ${ }^{51}$ Another study found that, in a comparison between HCAIs due to methicillin-sensitive $S$. aureus and methicillin-resistant $S$. aureus (MRSA), isolates were statistically significantly $(P<0.005)$ more resistant to ciprofloxacin, clindamycin, trimethoprim/sulfamethoxazole, erythromycin, gentamicin, and tetracycline. ${ }^{52}$ Hospital waste, especially contaminated surgical waste, often acts as a reservoir for pathogenic virulent microorganisms, and it suggested that $20 \%-25 \%$ of the waste produced by health care outlets is considered to have high potential to cause HCAIs, it therefore needs appropriate handling and disposal..$^{53,54}$

\section{Causative organisms}

Around $12-17$ microorganisms cause $80 \%-87 \%$ of HCAIs: S. aureus, Enterococcus species (eg, faecalis, faecium), E. coli, coagulase-negative Staphylococci, Candida species (eg, albicans, glabrata), K. pneumoniae and Klebsiella oxytoca, P. aeruginosa, A. baumannii, Enterobacter species, Proteus species, Yeast NOS, Bacteroides species, and other pathogens. ${ }^{45,55,56}$ Among these pathogens, 16\%-20\% include multidrug-resistant (MDR) phenotypes: MRSA, vancomycin-resistant $E$. faecium, carbapenem-resistant P. aeruginosa, extended-spectrum cephalosporin-resistant K. pneumoniae, K. oxytoca, E. coli, and Enterobacter species, and carbapenem-resistant $P$. aeruginosa, $K$. pneumoniae/ K. oxytoca, E. coli, Enterobacter species, and A. baumannii. ${ }^{45,55}$ Some of these Gram-negative microorganisms have a much higher rate $(20 \%-40 \%)$ of resistance than others ${ }^{45}$ with the organisms isolated from device-associated HCAIs having the highest antimicrobial resistance phenotypes. ${ }^{56} \mathrm{In}$ the latter study, although similar to the percentage resistance for most phenotypes was that in an earlier research study ${ }^{45}$ an upsurge in the scale of the resistance fractions against $E$. coli pathogens was observed, especially with fluoroquinolones. ${ }^{56}$ Acinetobacter, Burkholderia spp. and Pseudomonas spp. isolates were $100 \%$ were $92 \%$ resistant to cephalosporins respectively. Burkholderia spp. was again totally resistant to fluoroquinolones and Acinetobacter spp. and Pseudomonas spp. were $94.2 \%$ and $95.8 \%$ resistant, respectively. The same study reported that $86.4 \%$ Acinetobacter spp. and $62.5 \%$ Pseudomonas spp. showed a high resistance to carbapenems, the preferred drug regime in ICUs. Carbapenems were found more effective against Burkholderia spp. with $20 \%$ resistance..$^{57}$ In another study, Enterobacteriaceae community were found to be completely resistant to third-generation cephalosporins. ${ }^{58}$ Over $80 \%$ of the Klebsiella spp. community were resistant to ciprofloxacin, gentamicin, piperacillin, tazobactam, and imipenem showing $48.6 \%$ resistance. E. coli was equally resistant although carbapenems were effective in almost 
80\% cases. Although Citrobacter spp.-related HCAIs are a relatively minor proportion, they also show resistance toward cephalosporins, fluoroquinolones, and aminoglycosides. ${ }^{58}$ Another study reported that although the Acinetobacter spp. were $76.99 \%-92.01 \%$, resistant to most antimicrobials, only $30 \%$ of Acinetobacter spp. isolated were susceptible. ${ }^{59}$ It can be seen therefore that the causative pathogenic microorganisms differ from country to country as does patterns of resistance.

\section{Types of HCAls}

Alongside infections due to cross-contamination between patients and health workers, patients being susceptible to common infections due to diminished immune responses, and infections at surgery sites (SSIs), many HCAIs are due to implants and prostheses. These include central line-associated bloodstream infections (CLABSIs), catheter-associated UTIs, and ventilator-associated pneumonia (VAP)..$^{57,60,61}$

\section{CLABSIs}

CLABSIs substantially increase morbidity, mortality, and health care costs, and great attention has been paid to addressing these. ${ }^{62,63}$ As a consequence, in 2009, 25,000 fewer CLABSIs occurred in the ICUs of US hospitals than in 2001, a 58\% reduction, with about 6,000 lives saved and estimated financial savings of US\$414 million in potential excess health care costs, although the costs of reducing such infections is very high. ${ }^{64}$ It is estimated that it costs $\sim \$ 1.8$ billion between 2001 and 2009 to save an additional 27,000 lives. ${ }^{64}$ Despite this investment, a considerable number of CLABSIs still occur, especially in outpatient hemodialysis centers and inpatient wards. ${ }^{64}$ Another study also reported the link between CLABSIs and considerable morbidity and mortality, although there is a wide variation in reported infection rates (from $20 \%$ to $62.5 \%$ ) in emerging economies. ${ }^{65}$ A study conducted in Taiwan reported the occurrence of CLABSIs as 3.93 per 1,000 central-catheter days. ${ }^{66}$ The most common causative pathogens were Gram-negative (39.2\%), Gram-positive (33.2\%), and Candida spp. microorganisms $(27.6 \%) .{ }^{66}$ In this study, patients developed CLABSIs 8 days from the time of insertion of the central line catheter. ${ }^{66} \mathrm{Mul}-$ tivariate analysis showed that a higher Pitt bacteremia score (OR 1.41; 95\% $\mathrm{Cl}=1.18-1.68$ ) and the prolonged interval between the onset of CLABSIs and catheter removal (OR $1.10 ; 95 \% \mathrm{CI}=1.02-1.20$ ) were associated with higher death rates. ${ }^{66}$ Another similar study identified prolonged catheter in situ, pediatric ICU stay, and intravenous nutrition were significant prognosticators of peripherally inserted central catheter-related CLABSIs among hospitalized children. ${ }^{67}$

\section{SSIs}

SSIs (formerly termed "wound infections") are still one of the most common adverse events that occur in hospitalized patients undergoing surgery or in outpatient surgical measures, regardless of the advances in preventive procedures. ${ }^{68}$ SSI is the most common complication in postoperative surgical patients, associated with significant morbidity, high death rates, and financial stress on national budgets and individual patients. ${ }^{69-71}$ SSIs are defined as infections arising up to 30-90 days after surgery in patients receiving an organ, group of cells, or device and affecting both the incisional site and deeper tissues around the surgery location. ${ }^{72,73}$

The type of surgery determines the proportion of SSIs. Between $2 \%$ and $36 \%$ of patients may develop SSIs, with the highest risk for orthopedic followed by cardiac and intraabdominal surgery. ${ }^{14,72,74,75}$ The length of hospital stay for patients with SSIs increases from 4 to 32 days as compared with patients with no post-surgical infections. ${ }^{76-78}$ Approximately $25 \%$ of patients with SSIs develop severe sepsis and shock and are moved to an ICU. ${ }^{65}$ SSIs cause statistically significant morbidity, mortality, and financial burdens for individuals and for communities. ${ }^{69-71,78}$

HCAIs are common following cardiac surgery, with a reported incidence rate of between $5.0 \%$ and $21.7 \%,{ }^{79,80}$ often accompanied with multiple organ failure and prolonged hospital stays, leading to increased mortality rates. ${ }^{79,80}$ The three most common locations for HCAIs after cardiac surgery are lungs, central venous catheters, and surgical sites. ${ }^{69}$ SSIs followed by cardiac surgery classically present with localized cellulitis (erythema, warmth, and tenderness), purulent discharge, sternal instability, chest pain, and systemic upset with deep infections. ${ }^{81-83}$ SSIs are devastating for orthopedic patients as it is very difficult to rid the bones and joints of the infection. ${ }^{83}$ One Saudi Arabian study reported an incidence of SSIs in orthopedic patients of $2.55 \%$ (79 of 3,096 patients) with the most common pathogens being Staphylococcus species including MRSA (29.11\%); Acinetobacter species (21.5\%); Pseudomonas species (18.9\%), and Enterococcus species (17.7\%). ${ }^{84}$ Surgical wound contamination potentials, patients' clinical conditions, type of surgery, and length of surgery were variables statistically significantly associated with SSIs and should be viewed as risk factors. ${ }^{85}$ The movement and number of staff and the structural features of the operating theater also affect the incidence of SSIs. ${ }^{85,86}$ One study found that $73.33 \%$ cases of SSIs following orthopedic surgery were culture positive, and a total of 35 bacterial strains were isolated, among which $65.72 \%$ were Grampositive isolates and $34.28 \%$ were Gram-negative bacteria. ${ }^{87}$ 
About $68.6 \%$ of all bacterial isolates were resistant to cefuroxime used in the management of orthopedic SSIs. This study also found that diabetes mellitus, smoking, operations lasting more than 3 hours, the absence of antibiotic prophylaxis, and a history of previous surgery were positive risk factors associated with a significant upsurge in SSIs. ${ }^{87}$

SSIs comprise at least $14 \%-22.2 \%$ of all HCAIs for abdominal surgery ${ }^{88-90}$ and often lead to extended hospitalization and higher antimicrobial costs. ${ }^{71}$ The microorganisms generally involved in such SSIs include $S$. aureus, coagulasenegative Staphylococci and Enterococcus spp., and E. coli. ${ }^{71}$ $S$. aureus has been known to be a major cause of HCAIs for over 100 years. ${ }^{91}$ When first introduced, nearly all strains were susceptible to penicillin, but since its wide and often irrational use, $S$. aureus started to become resistant by producing $\beta$-lactamase enzyme. ${ }^{91}$ By $1960,95 \%$ hospital variants of $S$. aureus were resistant. ${ }^{91,92}$ To help combat resistance, several new penicillins were developed to resist Staphylococcal $\beta$-lactamase, such as methicillin, oxacillin, cloxacillin, and flucloxacillin. ${ }^{91}$ However, within 1 year of methicillin being marketed in 1960, the first MRSA strain of S. aureus was reported in England. ${ }^{93}$ The MRSA strain represents $50 \%$ of HCAIs in the US and Europe and causes infections that are very difficult to manage because of their potential resistance to multiple antimicrobials. ${ }^{94-96}$ In one study, the incidence of SSIs was after gastrectomy in $11.3 \%$, after colorectal surgery in $15.5 \%$, after hepatectomy in $11.3 \%$, and after pancreaticoduodenectomy in $36.9 \% .{ }^{97}$ While the incidence of SSIs was higher in the absorbable stitching material than the silk group for all surgical procedures, the difference was not statistically significant. ${ }^{97} \mathrm{~A}$ Japanese study on abdominal surgery reported an overall SSI rate of $14.4 \%$. The SSI rates in the suture-less, Vicryl, and silk groups were $4.8 \%, 14.8 \%$, and $16.4 \%,{ }^{88}$ respectively, again with no statistically significant differences between the groups. In colorectal surgery, the SSI rate in the polyglactin 910 (absorbable, synthetic, usually braided suture; Vicryl ${ }^{\mathrm{TM}}$ ) group was $13.9 \%$, which was statistically significantly lower than that of the silk group $(22.4 \% ; P=0.034)$. The incidence of deeper SSIs in the Vicryl group, including deep incisional SSIs (ISSIs) and organ/space SSIs (OSIs), was statistically significantly lower than that in the silk group $(P=0.04) .{ }^{88}$ The SSI rates did not differ among the suture types overall in gastric surgery or in appendectomy. ${ }^{98}$ A US study of pediatric patients found that while this was only $2.5 \%$ of the caseload, colorectal surgery contributed to $7.1 \%$ of the SSIs. ${ }^{98}$ The SSI rates of all types of colorectal surgery were $5.9 \%$ (ISSIs: $3.2 \%$; OSIs: $2.7 \%$ ) with the uppermost being total abdominal colectomy (11.4\%) trailed by partial colectomy $(8.3 \%)$ and colostomy closure $(5.0 \%) .{ }^{98}$ Inflammatory bowel diseases caused the topmost health problems in a comparison of all colorectal diagnosed diseases (24.9\%; ISSIs: 22\%; OSIs: 28.6\%). Hirschsprung's disease (14.2\%; ISSIs: $15.4 \%$; OSIs: $12.8 \%$ ) and anorectal malformations (12.4\%; ISSIs: $17.6 \%$; OSIs: $6.4 \%)$ were the next major group in colorectal diseases. ${ }^{98}$ Finally, a study utilizing univariate analysis defined 13 statistically significantly variables related to SSIs. Those were patients aged over 60 years, lower functional status, diabetes mellitus, congestive heart failure, immunocompromising disease, anticancer medications, immunosuppressive agents, impaired immune system, open cholecystectomy, laparotomy, an American Society of Anesthesiologists score above 2, drain insertion, and dirty wound. ${ }^{99}$ Using multivariate regression analysis, this study also found that immunosuppressive agents (OR $=2.5,95 \%, \mathrm{CI}=1.099-143.443)$, open cholecystectomy $(\mathrm{OR}$ $=2.25,95 \% \mathrm{CI}=2.242-40.109)$, and contaminated wound $(\mathrm{OR}=2.179,95 \% \mathrm{CI}=3.80-20.551)$ were statistically significantly linked with SSIs. ${ }^{99}$

\section{Catheter-associated urinary tract infections (CAUTIs)}

Internationally, UTIs are the most common HCAIs and one of the top ranking microbial infections, representing around $40 \%$ of HCAIs, with significant consequences for morbidity and mortality and substantial financial implications..$^{14,99,100}$ Although CAUTIs are typically benign, some patients have potentially pathogenic virulent bacteria but are asymptomatic, and these patients were associated with a three-times higher mortality than in non-bacteriuric patients. ${ }^{101,102}$ Multivariate analysis indicates the risk factors for CAUTIs including prolonging the duration of the catheter, female sex, older age, diabetes mellitus, the absence of systemic antibiotics, catheter insertion outside the operating room, and a breach in the closed system of catheter drainage. ${ }^{101,103}$ The rate of CAUTIs has been estimated to be about $5 \%$ per day, regardless of the duration of the indwelling catheter, with $E$. coli being the main infecting pathogenic microorganism, although a wide spectrum of other microorganisms were identified, including eukaryotic fungus. ${ }^{104,105}$ The repetitive inappropriate administration of antimicrobials often leads to greater bacterial resistance. CAUTIs habitually lead to biofilm formation on both the extraluminal and intraluminal portal catheter surface, largely from extraluminal microorganisms. ${ }^{106-108}$ The biofilm defends microbes from both antimicrobials and host defense mechanisms. ${ }^{109}$ Although morbidity from CAUTIs with shortterm catheter use is limited if catheters are appropriately 
inserted and cleaned, in patients with long-term indwelling catheters, fever from CAUTIs is common with a frequency fluctuating from one per 100 to one per 1,000 catheter days. ${ }^{105}$ Patients in institutional care with long-term indwelling catheters have a greater risk for the presence of pathogenic microorganisms and other urinary tract diseases than those without catheters. ${ }^{105}$ One meta-analysis found that CAUTIs were linked with statistically significantly higher death rates (OR $=1.99 ; 95 \% \mathrm{CI}=1.72-2.31 ; P<0.00001 ; \mathrm{I}^{2}=54 \%$; eight studies; 62,063 patients) and days in the ICU (weighted mean difference of +12 days; $95 \% \mathrm{CI}=9-15 ; P<0.00001 ; \mathrm{I}^{2}=96 \%$; seven studies; 13,011 patients) and hospital (mean difference +21 days; $95 \% \mathrm{CI}=11-32 ; P<0.0001 ; \mathrm{I}^{2}=98 \%$; five studies; 10,183 patients). ${ }^{110}$ An Australian health care-associated urinary tract infection (HCAUTI) non-concurrent cohort study carried out for 4 consecutive years found that patients had an extra 4 days (95\% CI $=3.1-5.0$ days) of hospitalization. ${ }^{111}$ This study further reported that the infection rate was statistically significantly minimized utilizing a Cox regression model $(\mathrm{HR}=0.78 ; 95 \% \mathrm{CI}=0.73-0.83$ ) when patients were released from the hospital. ${ }^{111}$ HCAUTIs very rarely cause death $(\mathrm{HR}=0.71 ; 95 \% \mathrm{CI}=0.66-0.75)$, especially in large hospitals when compared to other health care institutes, even when compared with age and sex $(\mathrm{HR}=0.74 ; 95 \% \mathrm{CI}$ $=0.69-0.78)$, although elderly patients more often died (HR $=1.40 ; 95 \% \mathrm{CI}=1.38-1.43) .{ }^{111}$

\section{VAP}

The death risk for patients in the ICU is not only because of their original illness but often because of HCAIs. ${ }^{2,54,112}$ Pneumonia is the second commonest HCAI in ICUs, affecting more than one-quarter of patients. ${ }^{13,114}$ Around $86 \%$ of HCAIs are associated with motorized automatic ventilation and VAP. ${ }^{113}$ Between $9 \%$ and $27 \%$ of patients with assisted ventilation develop this kind of pneumonia, and VAP has been identified internationally as a potential major cause of death. ${ }^{114}$ The average critical time to develop VAP following endotracheal intubation and mechanical ventilation was 2-3 days. ${ }^{115}$ Patients usually develop a fever, altered bronchial sounds, white blood cell counts reduced, changes in sputum, and causative organisms are often identified. ${ }^{116-121}$ A US study found a range of VAP of between 1.2 and 8.5 per 1,000 ventilator days ${ }^{122}$ although an international group reported a much higher occurrence of VAP of 13.6/1,000 ventilator days. ${ }^{123}$ In Asian countries, a different picture of 3.5-46 infections/1,000 ventilator days emerges, ${ }^{124}$ with a very high incidence rate in India of 40.1 per 1,000 ventilator days. ${ }^{125}$ The initial 5 days of mechanical ventilation is the most critical time for the development of
VAP, with a mean duration of 3.3 days between intubation and the development of VAP. ${ }^{119-126}$ Another recent Indian study reported that non-fermentative Gram-negative bacilli ${ }^{127}$ were the predominant organisms, followed by Pseudomonas and Klebsiella genus. In this study, S. aureus reduced in prevalence from 50\% to $34.9 \%$ between 2011 and 2013, but between 2012 and 2013 vancomycin-resistant Enterococci increased from $4.3 \%$ to $8.3 \%$, while methicillin resistance among $S$. aureus exceeded $50 \%$ in 2013 . In addition, an upwavard trend in resistance by Pseudomonas genus was observed for piperacillin-tazobactam, amikacin, and imipenem. The incidence of non-fermenters' resistance continued to be very high except for amikacin and imipenem (33.1\%) and polymyxin-B (2.4\%). ${ }^{127}$ A study at Chonnam National University Hospital in South Korea of the transtracheal aspirates or bronchoalveolar lavage of patients suffering from VAP found that S. aureus (44\%) was the most frequently detected causative microorganism followed by $A$. baumannii (30\%), P. aeruginosa (12\%), Stenotrophomonas maltophilia (7\%), K. pneumoniae (6\%), and Serratia marcescens (2\%). ${ }^{128}$ In addition, $S$. aureus was found as MRSA and 69\% of Acinetobacter baumannii were imipenem-resistant. ${ }^{128}$ No statistically significant variance was observed in the imipenem-resistant A. baumannii ${ }^{128}$ between the earlier and late VAP-related study groups $(73 \%$ [8/11] vs $67 \%$ [14/21], $P=1.000) .{ }^{128}$ In this study, $67 \%$ of $K$. pneumoniae was ESBL-positive. ${ }^{128}$ VAP was frequently linked with substantially increased morbidity, including prolonged ICU and hospitalization, and higher ventilator days and health care costs. ${ }^{129}$

In the UK and the Republic of Ireland, a European study of HCAIs connected with respiratory infection found a prevalence rate of $7.59 \%$. Among these HCAIs, $15.7 \%$ were pneumonia, and 7\% were lower respiratory tract infections other than pneumonia (LRTIOP). ${ }^{130}$ Around 21\% of patients in both the groups were having artificial ventilation, which was much higher when compared to the rest of the patients with HCAIs. MRSA was the principal invading microorganism for both pneumonia and LRTIOP. Although the patients with LRTIOP suffered more from $C$. difficileinduced diarrhea than pneumonia, this was not statistically significant. ${ }^{130}$ A recent Chinese study reported that $14.94 \%$ (895) of inpatients acquired a LRTI which prolonged their hospital stay and increased the costs per individual case by US $\$ 2,853.93 .{ }^{131}$ Another study revealed that $9.6 \%$ of patients developed HCAIs, of which respiratory tract infections were the highest at $65.8 \% .{ }^{132}$ The most frequently identified respiratory pathogen was Gram-negative Acinetobacter species (40.4\%), and among these $21 \%$ were MDR. ${ }^{132}$ 
A significant number of patients develop pneumonia after surgery which includes both hospital-acquired pneumonia (pneumonia developing 48-72 hours after admission) and (as discussed above) VAP (pneumonia developing 48-72 hours after endotracheal intubation). ${ }^{133}$ Postoperative pneumonia has been described as one of the leading consequences of all types of surgery with a high incidence of morbidity and mortality. ${ }^{134}$ It increases hospital stays on an average of 7-9 days and increases health care costs from US\$12,000 to US\$40,000. ${ }^{114,135,136}$

\section{HCAls}

HCAIs are a major safety concern for both health care providers and patients. They continue to escalate at an alarming rate, especially in emerging economies, with infection rates 3-20 times higher than in high-income countries. ${ }^{1,2,137}$ HCAIs increase morbidity, mortality, length of hospital stays, and costs; ${ }^{138-140}$ therefore, more research and changes in practice are needed to ensure hospital safety and prevent HCAIs. ${ }^{32,141-143}$ The annual costs for HCAIs alone in the USA are between US $\$ 28$ and US $\$ 45$ billion, but with even this amount of spending, 90,000 lives are still lost per year: HCAIs are among the top five killers in the USA. ${ }^{14,144-147}$ The WHO advocates that effective hand hygiene is the single most important practice to prevent and control HCAIs, which form colonies with MDR microbes. ${ }^{1,2,148,149}$ Several studies report that a simple and straightforward process, taking only a few seconds to clean hands with an alcohol-based hand rub helps prevent HCAIs and save lives, reduce morbidity, and minimize health care costs. ${ }^{150,151}$ However, factors such as the availability of alcohol-based hand rubs and up-to-date knowledge of the importance of hand washing hinder good practice in hand hygiene. For example, an Australian observational study of community nurses highlighted poor practices of hand hygiene in comparison with a standard protocol. ${ }^{152}$

The WHO promotes and advocates that all health care workers (HCWs) must wash their hands before touching a patient, before clean/aseptic procedures, after body fluid exposure/risk, after touching a patient, and after touching patient surroundings. ${ }^{153}$ The Center for Disease Control and Prevention has developed a comprehensive plan and guidelines for the prevention of HCAIs which covers basic infection prevention and control (IPC); antibiotic resistance; device- and procedure-associated infections; disease/ organism-specific infections; and guidance for health workers working in specific settings. ${ }^{154}$ This guidance, like that of the WHO and the UK Royal College of Nursing (RCN) also emphasizes the importance of hand washing. ${ }^{153-155}$ The RCN also promotes and advocates that all health care profes- sionals must receive compulsory "infection control training as part of their induction and on an ongoing annual basis. It is particularly important that knowledge and skills are continually updated." 155 Multiple research studies indicate that policy changes and the adoption of novel multifactorial, multimodal, multidisciplinary strategies offer the greatest possibility of success in terms of hand hygiene improvement and the reduction of HCAIs. ${ }^{156-167}$

Instigating best practice in health care stems "from a response to factors that are outside a purely scientific understanding of infection and not simply understood as a deficit in knowledge." ${ }^{168,169}$ Good practice for infection prevention among $\mathrm{HCWs}$ can be ensured through compliance to IPC guidelines. ${ }^{168}$ Specific individuals acting as "change champions" can act as arbitrators or negotiators, contributing to changing behaviors and implementing best practice to ensure patient safety. ${ }^{168-171}$ This calls for educational interventions that reflect the philosophies, principles, and community understanding of dirt and infection. ${ }^{169}$ An educational intervention involving 4,345 health professionals in three public hospitals in the USA successfully improved hand hygiene immensely with the use of alcohol hand rub. Nurses, physicians, and allied HCWs improved from $14 \%$ to $34 \%, 4.3 \%$ to $51 \%$, and $12 \%$ to $44 \%$, respectively. ${ }^{172}$ Other studies also highlight how behavior change around hand washing can result from educational interventions. ${ }^{149,151,172}$ Health professionals must protect themselves with barriers for example, gloves, gowns, face masks, protective eyewear, and face shields, ${ }^{173}$ to decrease the work-related transmission of microorganisms. Regular use of personal protective equipment (PPE) ${ }^{173}$ devices protects both the professional and the patient from potentially infectious body fluids. ${ }^{173}$ Nevertheless, the use of PPE does not confirm 100\% protection, ${ }^{174}$ for example, needlestick injury can breach PPE, and, in many occasions, issues might go unrecognized which might cause a dangerous health hazard including hepatitis B or HIV. ${ }^{175}$

Respiratory microorganisms, for example, influenza virus, Bordetella pertussis, Haemophilus influenzae, Neisseria meningitidis, and Mycoplasma pneumoniae, severe acute respiratory syndrome-associated coronavirus, Group A Streptococcus, adenovirus and rhinovirus, and tubercular bacilli ${ }^{176}$ are easily dispersed through droplets (particles $\leq 5$ $\mu \mathrm{m}$ in size) in closed health care settings and often cause endemics and epidemics. ${ }^{176}$ PPE, vaccines, and drugs are the main measures to prevent and control such infections. ${ }^{177}$ This includes national annual campaigns such as requiring all health professionals to have a flu vaccine. Multiple research studies have found that poor cleaning of hospital surfaces is a 
major source of HCAIs because of the transmission of many dangerous microorganisms such as MRSA, vancomycinresistant Enterococcus spp. (VRE), C. difficile, Acinetobacter spp., and norovirus. ${ }^{178-182}$ Meticulous cleaning of hospital surfaces is therefore vital to maintain standards and reduce the risk of HCAIs. ${ }^{183}$ Several studies conclude that ultraviolet devices and hydrogen peroxide vapor technologies successfully eradicate potentially dangerous hospital microorganisms adhering to the surfaces in ward or patient rooms. ${ }^{183-186}$ Furthermore, hydrogen peroxide vapor efficiently sterilizes and sanitizes all clinical areas where potentially dangerous microbial MDR microorganisms and spores were suspected to be present. ${ }^{187}$

\section{Conclusion}

In the early to mid-19th centuries in both Europe and USA, thousands of young women died from puerperal sepsis and fever, the diseases rampant in the charity maternity clinics of the time ${ }^{188}$ and, due to the efforts of (among others) Dr Ignaz Phillip Semmelweis and Dr Oliver Wendell Holmes, the fight against puerperal fever was won and it was confirmed that HCAIs were transmitted via the hands of HCWs. ${ }^{188-192}$ Despite the development of many hi-tech methods, hand washing with soap and water or alcohol rub is still the most important means of maintaining personal hygiene and preventing HCAIs. ${ }^{192}$ However, due to the rise of antibioticresistant bacteria and a reluctance of some HCWs to implement best practice infection control, HCAIs remain one of the biggest causes of death in most countries. Therefore, it is essential that strategic, policy, and education initiatives continue to focus on managing and controlling such (predominantly needless) infections.

\section{Limitations of the study}

The topic of HCAIs is a very broad issue, and it has therefore not been possible to cover all aspects of HCAIs in one paper; hence, we have been selective in selecting key aspects of the current debate.

\section{Acknowledgments}

The authors are grateful to Dr Zakirul Islam, Associate Professor and Head of The Department, Pharmacology and Therapeutics, Eastern Medical College, Comilla, Bangladesh for his cooperation in converting the video abstract from a PowerPoint file to video format.

\section{Disclosure}

The authors report no conflicts of interest in this work.

\section{References}

1. Collins A.S. Preventing Health Care-Associated Infections. In: Hughes RG, editor. Patient Safety and Quality: An Evidence-Based Handbook for Nurses. Rockville (MD): Agency for Healthcare Research and Quality (US); 2008 Apr. Chapter 41. Available from: https://www. ncbi.nlm.nih.gov/books/NBK2683/. Accessed April 1, 2018.

2. Revelas A. Healthcare - associated infections: A public health problem. Niger Med J. 2012;53(2):59-64.

3. Brennan TA, Leape LL, Laird NM, et al. Incidence of adverse events and negligence in hospitalized patients: results of the Harvard Medical Practice Study I. N Engl J Med. 1991;324(6):370-376.

4. Leape LL, Brennan TA, Laird N, et al. The nature of adverse events in hospitalized patients: results from the Harvard Medical Practice Study II. N Engl J Med. 1991;324(6):377-384.

5. Garrouste-Orgeas M, Philippart F, Bruel C, Max A, Lau N, Misset B. Overview of medical errors and adverse events. Ann Intensive Care. 2012;2(1):2.

6. Parameswaran Nair N, Chalmers L, Peterson GM, Bereznicki BJ, Castelino RL, Bereznicki LR. Hospitalization in older patients due to adverse drug reactions -the need for a prediction tool. Clin Interv Aging. 2016;11:497-505.

7. Desikan R, Krauss MJ, Dunagan WC, et al. Reporting of Adverse Drug Events: Examination of a Hospital Incident Reporting System. In: Henriksen K, Battles JB, Marks ES, et al, editors. Advances in Patient Safety: From Research to Implementation (Volume 1: Research Findings). Rockville (MD): Agency for Healthcare Research and Quality (US); 2005. Available from: https://www.ncbi.nlm.nih.gov/books/ NBK20453/. Accessed April 1, 2018.

8. Klevens RM, Edwards JR, Richards CL. Estimating health careassociated infections and deaths in U.S. hospitals, 2002. Public Health Rep. 2007;122(2):160-166.

9. Agency for Healthcare Research and Quality [webpage on the Internet]. Patient safety primers: healthcare-associated infections; 2012. Available from: https://www.ahrq.gov/professionals/quality-patient-safety/patientsafety-resources/resources/hais/index.html. Accessed April 3, 2018.

10. Danasekaran R, Mani G, Annadurai K. Prevention of healthcareassociated infections: protecting patients, saving lives. Int J Community Med Public Health. 2014;1(1):67-68.

11. World Alliance for Patient Safety [webpage on the Internet]. The Global Patient Safety Challenge 2005-2006 "Clean Care is Safer Care." Geneva: WHO; 2005. Available from: http://www.who.int/gpsc/en/. Accessed April 4, 2018.

12. Vincent J-L. Nosocomial infections in adult intensive-care units. Lancet. 2003;361(9374):2068-2077.

13. Kim JM, Park ES, Jeong JS, et al. Multicenter surveillance study for nosocomial infections in major hospitals in Korea. Nosocomial Infection Surveillance Committee of the Korean Society for Nosocomial Infection Control. Am J Infect Control. 2000;28(6):454-458.

14. Nuvials X, Palomar M, Alvarez-Lerma F, et al. Health-care associated infections. Patient characteristics and influence on the clinical outcome of patients admitted to ICU. Envin-Helics registry data. Intensive Care Med Exp. 2015;3(Suppl 1):A82.

15. Klavs I, Bufon Lužnik T, Skerl M, et al. Prevalance of and risk factors for hospital-acquired infections in Slovenia-results of the first national survey, 2001. J Hosp Infect. 2003;54(2):149-157.

16. Eriksen HM, Iversen BG, Aavitsland P. Prevalence of nosocomial infections in hospitals in Norway, 2002 and 2003. The French Prevalence Survey Study Group. J Hosp Infect. 2005;60(1):40-45.

17. Prevalence of nosocomial infections in France: results of the nationwide survey in 1996. J Hosp Infect. 2000;46(3):186-193.

18. Gikas A, Pediaditis J, Papadakis JA, et al; Greek Infection Control Network. Prevalence study of hospital-acquired infections in 14 Greek hospitals: planning from the local to the national surveillance level. $J$ Hosp Infect. 2002;50(4):269-275.

19. di Pietrantonj C, Ferrara L, Lomolino G. Multicenter study of the prevalence of nosocomial infections in Italian hospitals. Infect Control Hosp Epidemiol. 2004;25(1):85-87. 
20. Emmerson AM, Enstone JE, Griffin M, Kelsey MC, Smyth ET. The Second National Prevalence Survey of infection in hospitals--overview of the results. J Hosp Infect. 1996;32(3):175-190.

21. McLaws ML, Taylor PC. The Hospital Infection Standardised Surveillance (HISS) programme: analysis of a two-year pilot. J Hosp Infect. 2003;53(4):259-267.

22. WHO. Healthcare-associated infections. Fact Sheet. Available from: http://www.who.int/gpsc/country_work/gpsc_ccisc_fact_sheet_ en.pdf. Accessed April 1, 2018.

23. Johnson NB, Hayes LD, Brown K, Hoo EC, Ethier KA. Centers for Disease Control and Prevention (CDC). CDC National Health Report: leading causes of morbidity and mortality and associated behavioral risk and protective factors-United States, 2005-2013. MMWR Suppl. 2014;63(4):3-27.

24. McDermid RC, Stelfox HT, Bagshaw SM. Frailty in the critically ill: a novel concept. Crit Care. 2011;15(1):301.

25. Chernow B. Variables affecting outcome in critically ill patients. Chest. 1999;115(5 Suppl):S71-S76.

26. Sokol D. A guide to the Hippocratic Oath; 2008. Available from: http:// news.bbc.co.uk/2/hi/7654432.stm. Accessed April 3, 2018.

27. Beveridge WIB. The art of scientific investigation. Chapter IX. Revised Edition. WW Norton \& Company, New York; 1957: 114. Available from: https://ia600202.us.archive.org/7/items/artofscientifici00beve/ artofscientifici00beve.pdf. Accessed April 4, 2018.

28. McCannon CJ, Berwick DM, Massoud MR. The science of large-scale change in global health. JAMA. 2007;298(16):1937-1939.

29. McCannon CJ, Hackbarth AD, Griffin FA. Miles to go: an introduction to the 5 Million Lives Campaign. Jt Comm J Qual Patient Saf. 2007;33(8):477-484.

30. Janine Benyus. Brainy Quote; 2018. Available from: https://www. brainyquote.com/quotes/janine_benyus_560643. Accessed April 3, 2018.

31. Noakes TD, Borresen J, Hew-Butler T, Lambert MI, Jordaan E. Semmelweis and the aetiology of puerperal sepsis 160 years on: an historical review. Epidemiol Infect. 2008;136(1):1-9.

32. Sydnor ERM, Perl TM. Hospital Epidemiology and Infection Control in Acute-Care Settings. Clin Microbiol Rev. 2011;24(1):141-173.

33. Magill SS, Edwards JR, Bamberg W, et al; Emerging Infections Program Healthcare-Associated Infections and Antimicrobial Use Prevalence Survey Team. Multistate point-prevalence survey of health care-associated infections. N Engl J Med. 2014;370(13):1198-1208.

34. Magill SS, Hellinger W, Cohen J, et al. Prevalence of HealthcareAssociated Infections in Acute Care Hospitals in Jacksonville, Florida. Infect Control Hosp Epidemiol. 2012;3(3):283-291.

35. Magill SS, Wilson LE, Thompson DL, et al; Emerging Infections Program Hospital Prevalence Survey Team. Reduction in the Prevalence of Healthcare-Associated Infections in U. S. Acute Care Hospitals, 2015 vs 2011. Open Forum Infect Dis. 2017;4(Suppl 1):S49.

36. Cai Y, Venkatachalam I, Tee NW, et al. Prevalence of HealthcareAssociated Infections and Antimicrobial Use Among Adult Inpatients in Singapore Acute-Care Hospitals: Results From the First National Point Prevalence Survey. Clin Infect Dis. 2017;64(Supp1 2):S61-S67.

37. Cassini A, Plachouras D, Eckmanns T, et al. Burden of Six HealthcareAssociated Infections on European Population Health: Estimating Incidence-Based Disability-Adjusted Life Years through a Population Prevalence-Based Modelling Study. PLoS Med. 2016;13(10):e1002150.

38. Kritsotakis EI, Kontopidou F, Astrinaki E, Roumbelaki M, Ioannidou E, Gikas A. Prevalence, incidence burden, and clinical impact of healthcare-associated infections and antimicrobial resistance: a national prevalent cohort study in acute care hospitals in Greece. Infect Drug Resist. 2017;10:317-328.

39. Ling ML, Apisarnthanarak A, Madriaga G. The Burden of HealthcareAssociated Infections in Southeast Asia: A Systematic Literature Review and Meta-analysis. Clin Infect Dis. 2015;60(11):1690-1699.

40. Askarian M, Yadollahi M, Assadian O. Point prevalence and risk factors of hospital acquired infections in a cluster of university-affiliated hospitals in Shiraz, Iran. J Infect Public Health. 2012;5(2):169-176.
41. Tagoe DN, Desbordes KK. Investigating potential sources of transmission of healthcare-associated infections in a regional hospital, Ghana. Int J Appl Basic Med Res. 2012;2(1):20-24.

42. Santajit S, Indrawattana N. Mechanisms of Antimicrobial Resistance in ESKAPE Pathogens. Biomed Res Int. 2016;2016:2475067.

43. Rice LB. Federal funding for the study of antimicrobial resistance in nosocomial pathogens: no ESKAPE. J Infect Dis. 2008;197(8):1079-1081.

44. Mermel LA, Allon M, Bouza E, et al. Clinical practice guidelines for the diagnosis and management of intravascular catheter-related infection: 2009 Update by the Infectious Diseases Society of America. Clin Infect Dis. 2009;49(1):1-45.

45. Sievert DM, Ricks P, Edwards JR, et al; National Healthcare Safety Network (NHSN) Team and Participating NHSN Facilities. Antimicrobial-resistant pathogens associated with healthcare-associated infections: summary of data reported to the National Healthcare Safety Network at the Centers for Disease Control and Prevention, 2009-2010. Infect Control Hosp Epidemiol. 2013;34(1):1-14.

46. Boucher HW, Talbot GH, Bradley JS, et al. Bad bugs, no drugs: no ESKAPE! An update from the Infectious Diseases Society of America. Clin Infect Dis. 2009;48(1):1-12.

47. World Health Organization. The burden of health care-associated infection. In: WHO Guidelines on Hand Hygiene in Health Care: First Global Patient Safety Challenge Clean Care Is Safer Care. Chapter 3. Geneva: World Health Organization; 2009. Available from: https:// www.ncbi.nlm.nih.gov/books/NBK144030/. Accessed September 4, 2018

48. Amin AN, Deruelle D. Healthcare-associated infections, infection control and the potential of new antibiotics in development in the USA. Future Microbiol. 2015;10(6):1049-1062.

49. Galani I, Souli M, Daikos GL, et al. Activity of plazomicin (ACHN490) against MDR clinical isolates of Klebsiella pneumoniae, Escherichia coli, and Enterobacter spp. from Athens, Greece. JChemother. 2012;24(4):191-194.

50. Landman D, Kelly P, Bäcker M, et al. Antimicrobial activity of a novel aminoglycoside, ACHN-490, against Acinetobacter baumannii and Pseudomonas aeruginosa from New York City. J Antimicrob Chemother. 2011;66(2):332-334.

51. Cass RT, Brooks CD, Havrilla NA, et al. Pharmacokinetics and safety of single and multiple doses of ACHN-490 injection administered intravenously in healthy subjects. Antimicrob Agents Chemother. 2011;55(12):5874-5880.

52. Kumari J, Shenoy SM, Baliga S, Chakrapani M, Bhat GK. HealthcareAssociated Methicillin-Resistant Staphylococcus aureus: Clinical characteristics and antibiotic resistance profile with emphasis on macrolide-lincosamide-streptogramin B resistance. Sultan Qaboos Univ Med J. 2016;16(2):e175-e181.

53. Bagheri Nejad S, Allegranzi B, Syed SB, Ellis B, Pittet D. Health-careassociated infection in Africa: a systematic review. Bull World Health Organ. 2011;89(10):757-765.

54. Khan HA, Baig FK, Mehboob R. Nosocomial infections: Epidemiology, prevention, control and surveillance. Asian Pac J Trop Biomed. 2017;7(5):478-482.

55. Hidron AI, Edwards JR, Patel J, et al. NHSN annual update: antimicrobial-resistant pathogens associated with healthcare-associated infections: annual summary of data reported to the National Healthcare Safety Network at the Centers for Disease Control and Prevention, 2006-2007. Infect Control Hosp Epidemiol. 2008;29(11): 996-1011.

56. Weiner LM, Webb AK, Limbago B, et al. Antimicrobial-Resistant Pathogens Associated With Healthcare-Associated Infections: Summary of Data Reported to the National Healthcare Safety Network at the Centers for Disease Control and Prevention, 2011-2014. Infect Control Hosp Epidemiol. 2016;37(11):1288-1301.

57. Messina AF, Berman DM, Ghazarian SR, et al. The management and outcome of spinal implant-related infections in pediatric patients: a retrospective review. Pediatr Infect Dis J. 2014;33(7):720-723. 
58. Parajuli NP, Acharya SP, Mishra SK, Parajuli K, Rijal BP, Pokhrel BM. High burden of antimicrobial resistance among gram negative bacteria causing healthcare associated infections in a critical care unit of Nepal. Antimicrob Resist Infect Control. 2017;6(1):67.

59. Banerjee T, Mishra A, Das A, Sharma S, Barman H, Yadav G. High Prevalence and Endemicity of Multidrug Resistant Acinetobacter spp. in Intensive Care Unit of a Tertiary Care Hospital, Varanasi, India. $J$ Pathog. 2018;2018(2):9129083.

60. French Society for Hospital Hygiene. Surveillance and Prevention of healthcare associated infections; 2010. Available from: http://www. eunetips.eu/fileadmin/pdf/spi.fr.france_surveillance_and_prevention_of_healthcare-associated_infections.pdf. Accessed April 4, 2018.

61. U.S. Department of Health \& Human Services [webpage on the Internet]. Centers for Disease Control and Prevention. Types of Healthcareassociated Infections; 2014. Available from: https://www.cdc.gov/hai/ infectiontypes.html. Accessed April 4, 2018.

62. Blot SI, Depuydt P, Annemans L, et al. Clinical and economic outcomes in critically ill patients with nosocomial catheter-related bloodstream infections. Clin Infect Dis. 2005;41(11):1591-1598.

63. Saint S, Veenstra DL, Lipsky BA. The clinical and economic consequences of nosocomial central venous catheter-related infection: are antimicrobial catheters useful? Infect Control Hosp Epidemiol. 2000;21(6):375-380

64. U.S. Department of Health \& Human Services. Centers for Disease Control and Prevention. Vital Signs: Central Line-Associated Blood Stream Infections - United States, 2001, 2008, and 2009. MMWR. 2011;60:243-248.

65. Atilla A, Doğanay Z, Kefeli Çelik H, Demiră̆ MD, S Kiliç S. Central line-associated blood stream infections: characteristics and risk factors for mortality over a 5.5 -year period. Turk $J$ Med Sci. 2017;47(2):646-652.

66. Lin KY, Cheng A, Chang YC, et al. Central line-associated bloodstream infections among critically-ill patients in the era of bundle care. J Microbiol Immunol Infect. 2017;50(3):339-348.

67. Advani S, Reich NG, Sengupta A, Gosey L, Milstone AM. Central line-associated bloodstream infection in hospitalized children with peripherally inserted central venous catheters: extending risk analyses outside the intensive care unit. Clin Infect Dis. 2011;52(9): 1108-1115.

68. E. Patchen Dellinger. 2012. Surgical Site Infections. In: Elaine C. Jong, and Dennis L. Stevens, editors. Netter's Infectious Diseases 1 st ed. Philadelphia: Elsevier Saunders; 2012:295-298.

69. U.S. Department of Health \& Human Services. Centers for Disease Control and Prevention. National and State Healthcare-Associated Infections Progress report is based on 2014 data; 2016. Available from: https://www.cdc.gov/HAI/pdfs/progress-report/hai-progress-report. pdf. Accessed April 5, 2018.

70. Hagel S, Ludewig K, Frosinski J, et al. Effectiveness of a hospitalwide educational programme for infection control to reduce the rate of health-care associated infections and related sepsis (ALERTS)methods and interim results. Dtsch Med Wochenschr. 2013;138(3435):1717-1722. German

71. Owens CD, Stoessel K. Surgical site infections: epidemiology, microbiology and prevention. J Hosp Infect. 2008;70(Suppl 2):3-10.

72. Annual epidemiological report: Reporting on 2011 surveillance data and 2012 epidemic intelligence data. ECDC. 2013.

73. Centers for Disease Control and Prevention. Surgical Site Infection (SSI) Event; 2018. Available from: https://www.cdc.gov/nhsn/pdfs/ pscmanual/9pscssicurrent.pdf. Accessed September 2, 2018

74. Martin ET, Kaye KS, Knott C, et al. Diabetes and Risk of Surgical Site Infection: A Systematic Review and Meta-analysis. Infect Control Hosp Epidemiol. 2016;37(1):88-99.

75. Horan TC, Gaynes RP, Martone WJ, Jarvis WR, Emori TG. CDC definitions of nosocomial surgical site infections, 1992: a modification of CDC definitions of surgical wound infections. Infect Control Hosp Epidemiol. 1992;13(10):606-608.
76. Monge Jodra V, Sainz de Los Terreros Soler L, Diaz-Agero Perez C, Saa Requejo CM, Plana Farras N. Excess length of stay attributable to surgical site infection following hip replacement: a nested case-control study. Infect Control Hosp Epidemiol. 2006;27(12):1299-1303.

77. Kusachi S, Kashimura N, Konishi T, et al. Length of stay and cost for surgical site infection after abdominal and cardiac surgery in Japanese hospitals: multi-center surveillance. Surg Infect (Larchmt). 2012;13(4):257-265.

78. Tsai DM, Caterson EJ. Current preventive measures for healthcare associated surgical site infections: a review. Patient Saf Surg. 2014;8(1):42.

79. Michalopoulos A, Geroulanos S, Rosmarakis ES, Falagas ME. Frequency, characteristics, and predictors of microbiologically documented nosocomial infections after cardiac surgery. Eur J Cardiothorac Surg. 2006;29(4):456-460.

80. Kollef MH, Sharpless L, Vlasnik J, Pasque C, Murphy D, Fraser VJ. The impact of nosocomial infections on patient outcomes following cardiac surgery. Chest. 1997;112(3):666-675.

81. Joseph L, Jeanmonod RK. Delayed presentation of deep sternal wound infection. West J Emerg Med. 2014;15(2):134-136.

82. Rupprecht L, Schmid C. Deep Sternal Wound Complications: An Overview of Old and New Therapeutic Options. Open J Cardiovas Sur. 2013;6:9-19.

83. Hashemzadeh K, Hashemzadeh S. In-hospital outcomes of delayed sternal closure after open cardiac surgery. J Card Surg. 2009;24(1):30-33.

84. Al-Mulhim FA, Baragbah MA, Sadat-Ali M, Alomran AS, Azam MQ. Prevalence of Surgical Site Infection in Orthopedic Surgery: A 5-year Analysis. Int Surg. 2014;99(3):264-268.

85. Spagnolo AM, Ottria G, Amicizia D, Perdelli F, Cristina ML. Operating theatre quality and prevention of surgical site infections. J Prev Med Hyg. 2013;54(3):131-137.

86. Cristina ML, Sartini M, Schinca E, Ottria G, Spagnolo AM. Operating room environment and surgical site infections in arthroplasty procedures. J Prev Med Hyg. 2016;57(3):E142-E148.

87. Li GQ, Guo FF, Ou Y, Dong GW, Zhou W. Epidemiology and outcomes of surgical site infections following orthopedic surgery. Am J Infect Control. 2013;41(12):1268-1271.

88. Watanabe A, Kohnoe S, Shimabukuro R, et al. Risk factors associated with surgical site infection in upper and lower gastrointestinal surgery. Surg Today. 2008;38(5):404-412.

89. Smyth ET, Emmerson AM. Surgical site infection surveillance. J Hosp Infect. 2000;45(3):173-184.

90. Aga E, Keinan-Boker L, Eithan A, Mais T, Rabinovich A, Nassar F. Surgical site infections after abdominal surgery: incidence and risk factors. A prospective cohort study. Infect Dis (Lond). 2015;4 7(11):761-767.

91. Duerden B, Fry C, Johnson AP, Wilcox MH. The Control of MethicillinResistant Staphylococcus aureus Blood Stream Infections in England. Open Forum Infect Dis. 2015;2(2):ofv035.

92. Cristea OM, Zlatian OM, Dinescu SN, et al. A comparative study on antibiotic resistance of Klebsiella strains from surgical and intensive care wards. Curr Heal Sci J. 2016;42(2):169-179.

93. Jevons MP. “Celbenin" - resistant Staphylococci. BMJ. 1961;1(5219): 124-125.

94. Byrd KK, Holman RC, Bruce MG, et al. Methicillin-resistant Staphylococcus aureus-associated hospitalizations among the American Indian and Alaska native population. Clin Infect Dis. 2009;49(7):1009-1015.

95. Cimolai N. Methicillin-resistant Staphylococcus aureus in Canada: a historical perspective and lessons learned. Can J Microbiol. 2010;56(2):89-120.

96. Dulon M, Haamann F, Peters C, Schablon A, Nienhaus A. MRSA prevalence in European healthcare settings: a review. BMC Infect Dis. 2011;11(1):138.

97. Maehara Y, Shirabe K, Kohnoe S, et al. Impact of intra-abdominal absorbable sutures on surgical site infection in gastrointestinal and hepato-biliary-pancreatic surgery: results of a multicenter, randomized, prospective, phase II clinical trial. Surg Today. 2017;47(9):1060-1071. 
98. Feng C, Sidhwa F, Cameron DB, Glass C, Rangel SJ. Rates and burden of surgical site infections associated with pediatric colorectal surgery: insight from the National Surgery Quality Improvement Program. $J$ Pediatr Surg. 2016;51(6):970-974.

99. Foxman B. Epidemiology of urinary tract infections: incidence, morbidity, and economic costs. Dis Mon. 2003;49(2):53-70.

100. Tenke P, Mezei T, Bőde I, Köves B. Catheter-associated Urinary Tract Infections. Euro Urol Suppl. 2017;16(4):138-143.

101. Stamm WE. Catheter-associated urinary tract infections: Epidemiology, pathogenesis, and prevention. Am J Med. 1991;91(3):S65-S71.

102. Elvy J, Colville A. Catheter associated urinary tract infection: what is it, what causes it and how can we prevent it? J Infect Prev. 2009;10(2): $36-41$.

103. Leelakrishna P, Karthik Rao B. A study of risk factors for catheter associated urinary tract infection. Int JAdv Med. 2018;5(2):334-339.

104. Jacobsen SM, Stickler DJ, Mobley HLT, Shirtliff ME. Complicated Catheter-Associated Urinary Tract Infections Due to Escherichia coli and Proteus mirabilis. Clin Microbiol Rev. 2008;21(1):26-59.

105. Nicolle LE. Catheter associated urinary tract infections. Antimicrob Resist Infect Control. 2014;3(1):23

106. Nicolle LE. Catheter-related urinary tract infection. Drugs Aging. 2005;22(8):627-639.

107. Tambyah PA, Halvorson KT, Maki DG. A prospective study of pathogenesis of catheter-associated urinary tract infections. Mayo Clin Proc. 1999;74(2):131-136.

108. Barford JMT, Coates ARM. The pathogenesis of catheter-associated urinary tract infection. $J$ Infect Prev. 2009;10(2):50-56.

109. Roilides E, Simitsopoulou M, Katragkou A, Walsh TJ. How Biofilms Evade Host Defenses. Microbiol Spectr. 2015;3(3):1-10.

110. Chant C, Smith OM, Marshall JC, Friedrich JO. Relationship of catheter-associated urinary tract infection to mortality and length of stay in critically ill patients: a systematic review and meta-analysis of observational studies. Crit Care Med. 2011;39(5):1167-1173.

111. Mitchell BG, Ferguson JK, Anderson M, Sear J, Barnett A. Length of stay and mortality associated with healthcare-associated urinary tract infections: a multi-state model. J Hosp Infect. 2016;93(1):92-99.

112. Haniffa R, Isaam I, De Silva AP, Dondorp AM, De Keizer NF. Performance of critical care prognostic scoring systems in low and middleincome countries: a systematic review. Crit Care. 2018;22(1):18.

113. Richards MJ, Edwards JR, Culver DH, Gaynes RP. Nosocomial infections in medical intensive care units in the United States. National Nosocomial Infections Surveillance System. Crit Care Med. 1999;27(5):887-892.

114. Chastre J, Fagon JY. Ventilator-associated pneumonia. Am J Respir Crit Care Med. 2002;165(7):867-903.

115. McEachern R, Campbell GD Jr. Hospital-acquired pneumonia: epidemiology, etiology, and treatment. Infect Dis Clin North Am. 1998;12(3):761-779.

116. Koenig SM, Truwit JD. Ventilator-associated pneumonia: diagnosis, treatment, and prevention. Clin Microbiol Rev. 2006;19(4): 637-657.

117. Hunter JD. Ventilator associated pneumonia. BMJ. 2012;344: e3325.

118. Craven DE, Hjalmarson KI. Ventilator-associated tracheobronchitis and pneumonia: thinking outside the box. Clin Infect Dis. 2010;51(Suppl 1):S59-S66.

119. American Thoracic Society, Infectious Diseases Society of America. Guidelines for the management of adults with hospital-acquired, ventilator-associated, and healthcare-associated pneumonia. $\mathrm{Am} \mathrm{J}$ Respir Crit Care Med. 2005;171(4):388-416.

120. Koenig SM, Truwit JD. Ventilator-associated pneumonia: diagnosis, treatment, and prevention. Clin Microbiol Rev. 2006;19(4):637-657.

121. Kalanuria AA, Ziai W, Zai W, Mirski M. Ventilator-associated pneumonia in the ICU. Crit Care. 2014;18(2):208.

122. Skrupky LP, Mcconnell K, Dallas J, Kollef MH. A comparison of ventilator-associated pneumonia rates as identified according to the National Healthcare Safety Network and American College of Chest Physicians criteria. Crit Care Med. 2012;40(1):281-284.
123. Rosenthal VD, Maki DG, Jamulitrat S, et al; INICC Members. International Nosocomial Infection Control Consortium (INICC) report, data summary for 2003-2008, issued June 2009. Am J Infect Control. 2010;38(2):95-104.e2.

124. Chawla R. Epidemiology, etiology, and diagnosis of hospital-acquired pneumonia and ventilator-associated pneumonia in Asian countries. Am J Infect Control. 2008;36(4 Suppl):S93-S100.

125. Mathai AS, Phillips A, Isaac R. Ventilator-associated pneumonia: A persistent healthcare problem in Indian Intensive Care Units! Lung India. 2016;33(5):512-516.

126. Rello J, Ollendorf DA, Oster G, et al; VAP Outcomes Scientific Advisory Group. Epidemiology and outcomes of ventilator-associated pneumonia in a large US database. Chest. 2002;122(6):2115-2121.

127. Chaudhury A, Rani AS, Kalawat U, Sumant S, Verma A, Venkataramana B. Antibiotic resistance \& pathogen profile in ventilatorassociated pneumonia in a tertiary care hospital in India. Indian $J$ Med Res. 2016;144(3):440-446.

128. Chi SY, Kim TO, Park CW, et al. Bacterial Pathogens of Ventilator Associated Pneumonia in a Tertiary Referral Hospital. Tuberc Respir Dis. 2012;73(1):32-37.

129. Muscedere JG, Martin CM, Heyland DK. The impact of ventilatorassociated pneumonia on the Canadian health care system. J Crit Care. 2008;23(1):5-10.

130. Humphreys H, Newcombe RG, Enstone J, et al; Hospital Infection Society Steering Group. Four country healthcare-associated infection prevalence survey: pneumonia and lower respiratory tract infections. J Hosp Infect. 2010;74(3):266-270.

131. Yan T, Li Y, Sun Y, et al. Hospital-acquired lower respiratory tract infections among high risk hospitalized patients in a tertiary care teaching hospital in China: An economic burden analysis. $J$ Infect Public Health. 2018;11(4):507-513.

132. Pradhan NP, Bhat SM, Ghadage DP. Nosocomial infections in the medical ICU: a retrospective study highlighting their prevalence, microbiological profile and impact on ICU stay and mortality. JAssoc Physicians India. 2014;62(10):18-21.

133. Chughtai M, Gwam CU, Mohamed N, et al. The Epidemiology and Risk Factors for Postoperative Pneumonia. J Clin Med Res. 2017;9(6): 466-475.

134. Kazaure HS, Martin M, Yoon JK, Wren SM. Long-term results of a postoperative pneumonia prevention program for the inpatient surgical ward. JAMA Surg. 2014;149(9):914-918.

135. Rello J, Ollendorf DA, Oster G, et al; VAP Outcomes Scientific Advisory Group. Epidemiology and outcomes of ventilator-associated pneumonia in a large US database. Chest. 2002;122(6):2115-2121.

136. Warren DK, Shukla SJ, Olsen MA, et al. Outcome and attributable cost of ventilator-associated pneumonia among intensive care unit patients in a suburban medical center. Crit Care Med. 2003;31(5):1312-1317.

137. Cole M. Patient safety and healthcare-associated infection. BrJ Nurs. 2011;201122(17):1122-1126.

138. WHO. Report on the Burden of Endemic Health Care-Associated Infection Worldwide. WHO Press, WHO, Geneva, Switzerland; 2011. Available from: http://apps.who.int/iris/bitstream/handle/10665/80135/9789241501507_ eng.pdf? sequence=1. Accessed April 19, 2018.

139. Cosgrove SE. The relationship between antimicrobial resistance and patient outcomes: mortality, length of hospital stay, and health care costs. Clin Infect Dis. 2006;42(Suppl 2):S82-S89.

140. Graves N, Weinhold D, Tong E, et al. Effect of healthcare-acquired infection on length of hospital stay and cost. Infect Control Hosp Epidemiol. 2007;28(3):280-292.

141. Stone PW. Economic burden of healthcare-associated infections: an American perspective. Expert Rev Pharmacoecon Outcomes Res. 2009;9(5):417-422.

142. Head MG, Fitchett JR, Holmes AH, Atun R. Funding healthcareassociated infection research: a systematic analysis of UK research investments, 1997-2010. J Hosp Infect. 2014;87(2):84-91.

143. Glance LG, Stone PW, Mukamel DB, Dick AW. Increases in mortality, length of stay, and cost associated with hospital-acquired infections in trauma patients. Arch Surg. 2011;146(7):794-801. 
144. Scott RD. The direct medical costs of healthcare-associated infections in US hospitals and the benefits of prevention; 2009. Available from: https://www.cdc.gov/hai/pdfs/hai/scott_costpaper.pdf. Accessed April 19,2018

145. Leape LL, Berwick DM. Five years after To Err Is Human: what have we learned? JAMA. 2005;293(19):2384-2390.

146. Thibault R, Makhlouf AM, Kossovsky MP, et al. Healthcare-associated infections are associated with insufficient dietary intake: an observational cross-sectional study. PLoS One. 2015;10(4):e0123695.

147. Anderson RN. Deaths: leading causes for 1999. Natl Vital Stat Rep. 2001;49(11):1-87.

148. Rosenberg A. Hand Hygiene Barriers faced by Health Care Workers in The Gambia: A Health Belief Model Approach [master's thesis]. Södertörn University, School of Natural Sciences, Technology and Environmental Studies, Sweden; 2016. http:/www.diva-portal.org/smash/get/ diva2:1081964/FULLTEXT01.pdf. Accessed September 3, 2018.

149. Pittet D, Allegranzi B, Sax H, et al; WHO Global Patient Safety Challenge, World Alliance for Patient Safety. Evidence-based model for hand transmission during patient care and the role of improved practices. Lancet Infect Dis. 2006;6(10):641-652.

150. Voss A, Widmer AF. No time for handwashing!? Handwashing versus alcoholic rub: can we afford 100\% compliance? Infect Control Hosp Epidemiol. 1997;18(3):205-208.

151. Widmer AF, Conzelmann M, Tomic M, Frei R, Stranden AM. Introducing alcohol-based hand rub for hand hygiene: the critical need for training. Infect Control Hosp Epidemiol. 2007;28(1):50-54.

152. Felembam O, John WS, Shaban RZ. Hand hygiene practices of home visiting community nurses: perceptions, compliance, techniques, and contextual factors of practice using the World Health Organization's "five moments for hand hygiene". Home Healthc Nurse. 2012;30(3):152-160.

153. World Health Organization [webpage on the Internet]. My 5 Moments for Hand Hygiene. Infection prevention and control; 2009. Available from: http://www.who.int/infection-prevention/campaigns/cleanhands/5moments/en/. Accessed September 3, 2018.

154. Centers for Disease Control and Prevention [webpage on the Internet]. Healthcare Infection Control Practices Advisory Committee (HICPAC); 2018. Available from: https://www.cdc.gov/hicpac/index. html. Accessed September 4, 2018.

155. Royal College of Nursing. Good practice in infection prevention and control. Guidance for nursing staff; 2005. Available from: http://www. wales.nhs.uk/sites3/Documents/739/RCN\%20infection\%20control. doc.pdf. Accessed April 19, 2018.

156. McLaws ML. The relationship between hand hygiene and health careassociated infection: it's complicated. Infect Drug Resist. 2015;8:7-18.

157. Hynes N. A Hand Hygiene Education and Training Improvement Strategy in an Acute Hospital Setting [master's dissertation]. Dublin, Ireland: Royal College of Surgeons in Ireland; 2015. Available from: https://epubs.rcsi. ie/cgi/viewcontent.cgi?referer=https://www.google.com/\&httpsredir=1\& article $=1075 \&$ context $=$ mscttheses. Accessed April 19, 2018.

158. Gould DJ, Moralejo D, Drey N, Chudleigh JH. Interventions to improve hand hygiene compliance in patient care. Cochrane Database Syst Rev. 2010;9(9):CD005186.

159. Gould DJ, Moralejo D, Drey N, Chudleigh JH, Taljaard M. Interventions to improve hand hygiene compliance in patient care. Cochrane Database Syst Rev. 2017;9:CD005186.

160. Roberts JA, Cookson BD. The management, prevention, and control of Healthcare Associated Infections in Acute NHS Trusts in England - International Comparison and Review; 2009. Available from: https://www.nao.org.uk/wp-content/uploads/2009/06/MDA_International_comparisons.pdf. Accessed April 19, 2018.

161. Cole M. Social Construction of Hand Hygiene As a Simple Measure to Prevent Health Care Associated Infection [PhD thesis]. University of Nottingham, UK; 2014. Available from: http://eprints.nottingham. ac.uk/14426/1/Final_PhD_revision.pdf. Accessed April 19, 2018.

162. National Institute for Health and Care Excellence (NICE). Infection control. Quality standards and indicators. Briefing paper; 2013. Available from: https:/www.nice.org.uk/guidance/qs61/documents/ infection-control-briefing-paper2. Accessed April 19, 2018.
163. Lam BC, Lee J, Lau YL. Hand hygiene practices in a neonatal intensive care unit: a multimodal intervention and impact on nosocomial infection. Pediatrics. 2004;114(5):e565-e571.

164. Won SP, Chou HC, Hsieh WS, et al. Handwashing program for the prevention of nosocomial infections in a neonatal intensive care unit. Infect Control Hosp Epidemiol. 2004;25(9):742-746.

165. Zerr DM, Allpress AL, Heath J, Bornemann R, Bennett E. Decreasing hospital-associated rotavirus infection: a multidisciplinary hand hygiene campaign in a children's hospital. Pediatr Infect Dis J. 2005;24(5):397-403.

166. Rosenthal VD, Guzman S, Safdar N. Reduction in nosocomial infection with improved hand hygiene in intensive care units of a tertiary care hospital in Argentina. Am J Infect Control. 2005;33(7): 392-397.

167. Johnson PD, Martin R, Burrell LJ, et al. Efficacy of an alcohol/ chlorhexidine hand hygiene program in a hospital with high rates of nosocomial methicillin-resistant Staphylococcus aureus (MRSA) infection. Med J Aust. 2005;183(10):509-514.

168. Williams L, Rycroft-Malone J, Burton CR. Implementing best practice in infection prevention and control. A realist evaluation of the role of intermediaries. Int J Nurs Stud. 2016;60:156-167.

169. Jackson C, Lowton K, Griffiths P. Infection prevention as "a show": a qualitative study of nurses' infection prevention behaviours. Int J Nurs Stud. 2014;51(3):400-408.

170. Edwards R, Charani E, Sevdalis N, et al. Optimisation of infection prevention and control in acute health care by use of behaviour change: a systematic review. Lancet Infect Dis. 2012;12(4):318-329.

171. Sax H, Allegranzi B, Uçkay I, Larson E, Boyce J, Pittet D. 'My five moments for hand hygiene': a user-centred design approach to understand, train, monitor and report hand hygiene. J Hosp Infect. 2007;67(1):9-21.

172. Wisniewski MF, Kim S, Trick WE, Welbel SF, Weinstein RA. Chicago Antimicrobial Resistance Project. Effect of education on hand hygiene beliefs and practices: a 5-year program. Infect Control Hosp Epidemiol. 2007;28(1):88-91.

173. Santana SL, Furtado GH, Coutinho AP, Medeiros EA. Assessment of healthcare professionals' adherence to hand hygiene after alcoholbased hand rub introduction at an intensive care unit in São Paulo, Brazil. Infect Control Hosp Epidemiol. 2007;28(3):365-367.

174. Roberge RJ. Face shields for infection control: A review. J Occup Environ Hyg. 2016;13(4):235-242.

175. Bhimji SS, Whitten R. Needlestick. [Updated 2018 Mar 14]. In: StatPearls [Internet]. Treasure Island (FL): StatPearls Publishing; January 2018. Available from: https://www.ncbi.nlm.nih.gov/books/ NBK493147/. Accessed September 3, 2018.

176. The University of California [webpage on the Internet]. Personal Protective Equipment (PPE). Environmental Health \& Safety; 2017. Available from: https://ehs.ucsc.edu/programs/safety-ih/ppe.html. Accessed May 25, 2018.

177. Fernstrom A, Goldblatt M. Aerobiology and its role in the transmission of infectious diseases. J Pathog. 2013;2013:493960.

178. Institute of Medicine (US) Committee on Personal Protective Equipment for Healthcare Personnel to Prevent Transmission of Pandemic Influenza and Other Viral Respiratory Infections. Current research issues. 1. Introduction. In: Larson EL, Liverman CT, editors. Preventing Transmission of Pandemic Influenza and Other Viral Respiratory Diseases: Personal Protective Equipment for Healthcare Personnel: Update 2010. Washington, DC: National Academies Press (US); 2011. Available from: https://www.ncbi.nlm.nih.gov/books/NBK209580/. Accessed May 25, 2018.

179. Weber DJ, Rutala WA, Miller MB, Huslage K, Sickbert-Bennett E. Role of hospital surfaces in the transmission of emerging health careassociated pathogens: norovirus, Clostridium difficile, and Acinetobacter species. Am J Infect Control. 2010;38(5 Suppl 1):S25-S33.

180. Otter JA, Yezli S, Salkeld JA, French GL. Evidence that contaminated surfaces contribute to the transmission of hospital pathogens and an overview of strategies to address contaminated surfaces in hospital settings. Am J Infect Control. 2013;41(5 Suppl):S6-S11. 
181. Weber DJ, Anderson DJ, Sexton DJ, Rutala WA. Role of the environment in the transmission of Clostridium difficile in health care facilities. Am J Infect Control. 2013;41(5 Suppl):S105-S110.

182. Weber DJ, Anderson D, Rutala WA. The role of the surface environment in healthcare-associated infections. Curr Opin Infect Dis. 2013;26(4):338-344.

183. Siani H, Maillard JY. Best practice in healthcare environment decontamination. Eur J Clin Microbiol Infect Dis. 2015;34(1):1-11.

184. Leas BF, Sullivan N, Han JH, Pegues DA, Kaczmarek JL, Umscheid CA. Environmental Cleaning for the Prevention of Healthcare-Associated Infections. Rockville, MD: Agency for Healthcare Research and Quality (US); August 2015. Report No.: 15-EHC020-EF. AHRQ Comparative Effectiveness Technical Briefs.

185. Dancer SJ. Controlling hospital-acquired infection: focus on the role of the environment and new technologies for decontamination. Clin Microbiol Rev. 2014;27(4):665-690.

186. Han JH, Sullivan N, Leas BF, Pegues DA, Kaczmarek JL, Umscheid CA. Cleaning Hospital Room Surfaces to Prevent Health Care-Associated Infections: A Technical Brief. Ann Intern Med. 2015;163(8):598-607.
187. Lemmen S, Scheithauer S, Häfner H, Yezli S, Mohr M, Otter JA. Evaluation of hydrogen peroxide vapor for the inactivation of nosocomial pathogens on porous and nonporous surfaces. Am J Infect Control. 2015;43(1):82-85.

188. Lane HJ, Blum N, Fee E. Oliver Wendell Holmes (1809-1894) and Ignaz Philipp Semmelweis (1818-1865): preventing the transmission of puerperal fever. Am J Public Health. 2010;100(6):1008-1009.

189. Dunn PM. Oliver Wendell Holmes (1809-1894) and his essay on puerperal fever. Arch Dis Child Fetal Neonatal Ed. 2007;92(4): F325-F327.

190. WHO. 4. Historical perspective on hand hygiene in health care. WHO Guidelines on Hand Hygiene in Health Care: First Global Patient Safety Challenge Clean Care Is Safer Care. Geneva: WHO; 2009. Available from: https://www.ncbi.nlm.nih.gov/books/NBK144018/. Accessed April 20, 2018.

191. Mathur P. Hand hygiene: back to the basics of infection control. Indian J Med Res. 2011;134(5):611-620.

192. Cutter IS, Viets HR. A Short History of Midwifery. Philadelphia; London: W. B. Saunders Company; 1964:99.
Infection and Drug Resistance

\section{Publish your work in this journal}

Infection and Drug Resistance is an international, peer-reviewed openaccess journal that focuses on the optimal treatment of infection (bacterial, fungal and viral) and the development and institution of preventive strategies to minimize the development and spread of resistance. The journal is specifically concerned with the epidemiology of antibiotic

\section{Dovepress}

resistance and the mechanisms of resistance development and diffusion in both hospitals and the community. The manuscript management system is completely online and includes a very quick and fair peerreview system, which is all easy to use. Visit http://www.dovepress.com/ testimonials.php to read real quotes from published authors. 